\title{
Criminal Investigation Polres Kudus Unit Efforts In The Prevention Of The Corruption In Village Funds Management
}

\author{
Luk Har Syan'in ${ }^{1}$, Gunarto $^{2}$ and Widayati ${ }^{3}$
}

Abstract. Interest and research efforts is to know the Kudus Police Criminal Investigation Unit of the Prevention of Corruption Within the Village Fund Management.

Corruption as a criminal act detrimental to state finance, society and individuals, classified as white collar crime is the main enemy of the Indonesian people in addition to narcotics and terrorism. Combating corruption not only through law enforcement (repression) but preventive measures should be preferred. Village Fund aims to promote the welfare of rural communities through its programs, so that should be the prevention of irregularities in utilization as well as in the village in the village Karangmalang, District Gebog, Kudus

Understanding of research results Karangmalang village residents, still very little about corruption, as well as the importance of the role of citizens in preventing corruption adi trans particularly as regards management of village funds. There are some obstacles and constraints encountered in reality on the ground by the Society and the Village Padurenan, District Gebog, Kudus Regency in respect of the management of village funds, and in particular as prevention of corruption use village funds, but the fund management nice village, transparent, and accountable in accordance with the statutory provisions of supported community participation oversee and report slogans, as one prevention of corruption to increase the effectiveness fitas development and welfare of rural communities in the vicinity.

Keywords: Prevention of Corruption Act; Village Fund.

\section{Introduction}

Corruption categorized as extraordinary crime because the impact was remarkable, that has been happening in a systematic and widespread, not only state financial harm, disrupt the stability and security of society and weakens democratic values, ethics, justice and legal certainty, also has violated the rights of the social and economic society at large. So great is the impact of corruption that led to the perception that its eradication must be done is incredible.

Corruption in this country as deeply rooted and spread that usually occur in the central government, now has penetrated even at lower levels such as in the area and villages. Not only in government, but has reached the courts, corporate, education, all aspects of life.

\footnotetext{
${ }^{1}$ Student of Master of Law, Universitas Islam Sultan Agung Semarang and Members of the Indonesian National Police (Polri), Email: tipidkor3kudus@gmail.com

${ }^{2}$ Faculty of Law Universitas Islam Sultan Agung

${ }^{3}$ Faculty of Law Universitas Islam Sultan Agung
} 
Combating corruption is a major task that must be resolved. Impossible to realize development, fight poverty, improve education and health but corruption is still rampant. Because it can be said corruption was the origin of any serious crime, such as; money laundering, the crime of gambling, prostitution, banking and others.

Like a disease, corruption in Indonesia has progressed in three phases elitist, endemic and systemic. At this stage of elitist, corruption remains a social pathology which is typical in the elite neighborhood / officials. At this stage of endemic, endemic corruption reaching broad layers of society. Then at a critical stage, when corruption becomes systemic, each individual in the system similar disease. Perhaps the disease of corruption in this country has reached the stage of systemic. ${ }^{4}$

Prevention of corruption can be reached with preventive efforts. Preventive efforts are made obstacles or barriers to prevent corruption. To be able to create a barrier or obstacle corruption will require thorough understanding of all the factors that cause corruption and all the things that support or influence. ${ }^{5}$ Efforts to prevent (preventive) against corruption is one way to combat the perpetrators of corruption so that future offenders who wish to directly harm the state finances did not dare to commit an act of corruption.

The granting of the village fund which is determined more precisely the imagination not much drag village head into corruption cases. Such as corruption Kudus District Government Village Fund, in the village of Padurenan, District Gebog, Kudus. ${ }^{6}$

Based on the foregoing, the Indonesian government worth more incentive to eradicate corruption, eradicate more emphasis we will an action that has occurred (repressive), like cutting the grass, after being cut and then grew thick again, that corruption, we do the eradication of corruption means a criminal offense it has been implemented, because if it has not been done, we also can not know it was corruption or not. "Criminal Investigation Polres Kudus Unit Efforts In The Prevention Of The Corruption In Village Funds Management".

Based on the description above, this study aims to determine 1) Efforts Kudus Police Criminal Investigation Unit in the prevention of criminal acts in Kudus District on village fund management; 2) The enforcement of the law against corruption in the management of village fund in the Kudus Police; 3) Factors that hamper efforts to prevent the crime of fund management village in Kudus and how the solution.

\section{Research Methods}

The method used is qualitative analysis, namely data obtained through fieldwork and research literature then arranged systematically, and then analyzed qualitatively to achieve clarity issues to be discussed. The data is then analyzed using a theoretical and

\footnotetext{
${ }^{4}$ Abu Fida dan Abdu Rafi, 2006, Terapi Penyakit Korupsi dengan Tazkiyatun Nafs (Penyucian Jiwa), Jakarta, Republika, p. 21.

${ }^{5}$ Leden Marpaung, 2001, Tindak Pidana Korupsi (Pemberantasan dan Pencegahan), Jakarta, Djambatan, p. 74.

${ }^{6}$ Preriset in Kudus Police, October $2^{\text {nd }}, 2018$.
} 
interpretive positive law which has been poured and then deductively conclude to address existing problems. ${ }^{7}$

\section{Results and Discussion}

\subsection{Criminal Investigation Polres Kudus Unit Efforts In The Prevention Of The Corruption In Village Funds Management}

Corruption is the use of public office for a purpose beyond official interests. Corruption itself consists of various types: bribery, extortion, influence peddling, nepostisme, fraud, kickbacks, embezzlement and so forth. We tend to view corruption as a mere sin eyes of government, but in fact many private parties involved in corruption in the government sector. We are all involved, so we must join hands and work together to find a way out.

Some legal expert opinion and formulating a definition of corruption in legislation, there are some elements of absolute or subject of corruption, such as:

- the perpetrator or perpetrators of corruption;

- their actions that violate the norms applicable in this form the moral (religious aspect), ethics (professional aspects), as well as laws and regulations (legal aspects);

- the element of financial harm / wealth of the country or the people, directly or indirectly, as well;

- there is an element or goals for personal interest or gain / family / group.

\subsection{Law Enforcement Against Corruption In The Management Of Village Fund In The Kudus Police}

The sentence imposed on the perpetrators of corruption bribe or bribery in accordance with Article 5, paragraph 1, letter (a) of Act No. 31 of 1999 jo Act No. 20 of 2001 numbers (1) shall be punished with imprisonment of minimum 1 year and most longer than 5 years, or fined at least 50 million and a maximum of 250 million rupiah each person who: (a) give or promise anything to an official, or state officials with the intention that public servants or organizers do or not do something in his post, which is contrary to his duty; or (b) give something to an official or state officials due to or associated with something that is contrary to the obligation to do or not do in his position.

Based on interviews with Criminal Police, Adj. Kudus ${ }^{8}$ that to describe some of the types of law enforcement in the management of the Village Fund. This is demonstrated behaviors in the management of the Village Fund who perform acts that could harm the state or practice of bribery. The thing that may be regarded as a normal act is giving a gift. Including criminal accountability in the management of the Village Fund is giving a gift to an official or village that because of his position in the management of the Village Fund. It is mentioned in article 13 of Act No. 31 of 1999 jo Act No. 20 of 2001: "Any person who gives gifts to public servants by considering the power and

\footnotetext{
${ }^{7}$ Ibid, p.119

${ }^{8}$ Invisible Criminal Police Interview of Kudus
} 
authority inherent in the office or position or by giving a gift or promise is inherent the position or the position, shall be punished with imprisonment of 3 years and or a fine of 150 million rupiah."

\subsection{What Factors Are Inhibiting Efforts To Prevent The Crime Of Fund Management Village In Kudus And How The Solution}

Some of them simply because of administrative errors or processes that are not transparent. Commission examines in the management of village fund has weakness in four aspects of the regulatory, governance, monitoring and human resources of village fund. ${ }^{9}$

So we need to realize that the prevention and eradication of corruption is a very big job, heavy, complex and complicated and high risk on law enforcement officials, tar ore to the community members who participated to report corruption, the absolute need to make various strategies. Therefore the problem of corruption is not only the responsibility of law enforcement but the participation of all elements of society must be involved.

Similarly terms of implementation of an ideal village fund use and appropriate arrangements applicable law, in the village Karangmalang, District Gebog, Kudus not too despite the problems faced. Here are some of the obstacles and constraints encountered in reality on the ground by the Society as well as devices in Padurenan Village, District Gebog, Kudus Regency in respect of the management of funds as well as the villages in particular as prevention of corruption use of funds of the village.

First, Human Resources (HR) provided still low in terms of knowledge or skills in penggelolaan village funds, so that the necessary assistance and guidance from the government, which is deeply felt constraint is human resources information technology still needs to be enforced ihan many fish plate. As well as difficulties in understanding about the rules of the use of funds and

\section{Closing}

\subsection{Conclution}

- Liability criminal laws driver of the vehicle against the negligence of the traffic that resulted in the death of the victim diatrur in Article 22 paragraph 4 letter $\mathrm{c}$ of Act No. 22 of 2009 about traffic and road transport Punishment has been progressing, ie from goal retaliation moving towards coaching for the defendant back into a human good and useful to society.

- The application of criminal law is immaterial to the traffic negligence causing death of the victim is an element of death or serious injury victims are met the decision No. 89 / Pid.Sus / 2016 / PN.Kds. Judges forum use a single indictment, namely

\footnotetext{
${ }^{9}$ https://news.detik.com/berita/d-3584184/kpk-soroti-4-kelemahan-dana-desayang-buka-peluangkorupsi, accessed on October 14, 2018
} 
Article 310 paragraph (4) of Act No. 22 of 2009 on Traffic and Transportation where elements of the indictment has been taken as proved by the judges. Where, between the act and the elements of each to the correct article. And by saving Writer application of the substantive law in the case has been in accordance with the criminal law in Indonesia.

- The judge in the convict consideration in the decision No. 89 / Pid.Sus / 2016 / PN.Kds consideration of criminal responsibility, in this case the judges based on facts arising in the trial judge that the defendant is accountable for acts committed by the consideration that at the time of his actions the defendant aware of the consequences caused, the offender in performing actions that are in a healthy condition and capable to consider his actions. There is an element against the law, and the absence of a criminal deletion reason.

\subsection{Suggestion}

- The judges in the decision by the criminal provisions governing the elimination of criminal sanctions imposed are not proportional to the crime, and suffering experienced by the victim's family for life. However, when considering have any peace between the families of the victims and the accused, then the real criminal is no longer much meaning for the families of the victims. Therefore, it has been their peace means the victim's family to forgive and forgive the accused.

- The General Prosecutor should be thorough and meticulous in preparing the indictment, given the indictment is the basis for the judge to impose or not impose punishment against perpetrators who are confronted in court, in addition, must also have the knowledge or science of law well, not only the law formally, but also materially law so that no one in deciding which actions are in accordance with the elements as indicted.

- The judge did not necessarily warrant based on the Public Prosecutor in Criminal dropping, but on the two legal evidence coupled with the judge's conviction. Judges should be more sensitive to seeing what facts that arise during the trials, so that from the fact that these arise, leading to the judge's conviction that the defendant may or may not be convicted.

\section{Bibliography}

[1] Achmad Ali. 2002, Menguak Tabir Hukum, Edisi kedua. PT Toko Gunung Agung tbk, Jakarta.

[2] Amir llyas. 2012. Asas-asas Hukum Pidana. Rangkang Education, Yogyakarta.

[3] Bambang Sugugono, 2003, Metode Penelitian hukum, PT Raja Grafindo Persada, Jakarta.

[4] Leden Marpaung. 2005. Asas, Teori, Praktik Hukum Pidana. Sinar Grafika : Jakarta.

[5] Moeljatno,L. 2002. Asas-asas Hukum Pidana. Rineka Cipta : Jakarta.

[6] M. Solly Lubis. 2002, Ilmu Negara, Cetakan Ke-5. Mandar Maju : Bandung.

[7] P.A.F. Lamintang. 1997..Dasar-dasar Hukum Pidana di Indonesia. PT. Citra Aditya Bakti : Bandung. 
[8] Pandang Rusli Effendy. 1989. Asas-Asas Hukum Pidana. Lembaga Kriminologi Unhas : Ujung.

[9] Soerjono Soekamto, 1987, Pengantar Peneltian Hukum, Universitas Indonesia Press, Jakarta.

[10] Wirjono Prodjodikoro 2003. Asas-Asas Hukum Pidana di Indonesia, Refika Aditama, Bandung.

[11] ---------------. 2003 Asas-Asas Hukum Pidana di Indonesia. Refika Aditama, Bandung.

[12] Y. Kanter dan S.R. Sianturi,. 1982, .Asas-Asas Hukum Pidana disertai Pembahasan Beberapa Perbuatan Pidana Yang Penting, PT Tiara Ltd : Jakarta. 